\title{
Composition of organic-mineral complexes (OMC) migrating in the reclaimed sod-podzolic soils (Umbric Albeluvisol Abruptic)
}

\author{
$A V$ Litvinovich $^{1}, O Y u$ Pavlova $^{1}, A V$ Lavrishchev $^{2, *}$, and $A A$ Belimov $^{3}$ \\ ${ }^{1}$ Agrophysical Research Institute, Grazhdanskiy pr., 14, 195220 St. Petersburg, Russia \\ ${ }^{2}$ St. Petersburg State Agrarian University, Petersburgskoe shosse, 2, 196601 St. Petersburg, Pushkin, \\ Russia \\ ${ }^{3}$ All-Russia Research Institute of Agricultural Microbiology, Podbelsky shosse, 3, 196608 St. \\ Petersburg, Pushkin, Russia
}

\begin{abstract}
The composition of organo-mineral complexes (OMC) migrating from the arable horizon limed by Umbric Albeluvisol Abruptic was studied. The carbon content in organic-mineral complexes (OMC) ranged from 5.5 to $5.7 \%$. The optical density index $\left(\mathrm{E}_{\mathrm{s}} \mathrm{mg} / \mathrm{ml}\right)$ varied in the range of values from 2.7 to 3.1, characteristic for fulvic acids (FA). It was established that FAs averaged with bases retain the ability to exert a destructive effect on soil minerals, transferring a significant amount of $\mathrm{Al}$, $\mathrm{Mn}$, and $\mathrm{Fe}$ into solution. According to their ability to migrate as part of $\mathrm{OMC}$, the elements studied in the experiment with dolomite particles at a dose of 7.35 t/ha were arranged in the following decreasing sequence: $\mathrm{Mn}$ $>\mathrm{Al}>\mathrm{Fe}$. In the experiment with conversion chalk (CC) at a dose of 20.25 $\mathrm{t} / \mathrm{ha}$, this sequence was $\mathrm{Al}>\mathrm{Mn}>\mathrm{Fe}$.
\end{abstract}

\section{Introduction}

Water-soluble organic substances (WOS) are able to form stable compounds of complex nature with aluminum, manganese, and iron ions [1-5]. There is a close correlation between soil acidity and the mobilization of aluminum and iron from the crystal lattice of minerals [6-7].

The main role in the migration processes occurring in Umbric Albeluvisol Abruptic belongs to compounds of fulvic acid nature, which are actively involved in the movement of aluminum, manganese and iron in their profile.

With an excess of bases in the soil solution and bringing the latter to an alkaline reaction $(\mathrm{pH}>10), \mathrm{OMC}$ with $\mathrm{FA}-1$ precipitate [8]. The scale of migration of the $\mathrm{Ca}, \mathrm{Mg}$, and $\mathrm{Sr}$ bases in the $\mathrm{OMC}$ of the reclaimed screening dolomite Umbric Albeluvisol Abruptic is quite significant [9].

With increasing $\mathrm{pH}$ of the soil solution due to liming, the cation-exchange capacity (CEC) of soil also increases. In the experiments [10] with a single application of $1 \mathrm{Ng}$ of lime due to the involvement of weakly acidic soil organic substances (OS) in the exchange

\footnotetext{
* Corresponding author: av.lavrishchev@yandex.ru
} 
processes in the composition of humic acids, more and more reactive groups can be activated, which were previously blocked by internal chemical bonds or could not be activated at lower $\mathrm{pH}$ values of solutions, the cation-exchange capacity increased by 10 $15 \%$. As a result of liming, the CEC can increase up to $48 \%$ with periodic liming of $1 \mathrm{Ng}$ to $23-29 \%$ according to the authors.

This creates an opportunity for the interaction of the "free" functional groups of humic acids of the lime soils with other typomorphic elements (Al, Mn, Fe).

Studies aimed at establishing the mobility of aluminum, manganese, and iron as part of the OMC of soils limed by industrial waste are unknown to us.

The purpose of the research was to establish the extent of migration of $\mathrm{Al}, \mathrm{Mn}$, and $\mathrm{Fe}$ as part of the OMC Umbric Albeluvisol Abruptic, reclaimed by industrial waste, in laboratory experiments on columns.

Research Objectives:

- establish the carbon content in OMC removed during washing of lime soils;

- determine the optical density of the OMC solutions that precipitate when the $\mathrm{pH}$ of the eluates is adjusted to 13 units;

- to conduct a ranking of typomorphic elements according to their ability to join compounds with WOS, migrating in reclaimed soils.

\section{Materials and methods}

Two laboratory experiments were performed. Samples of reclaimed soils were taken from plots of the microfield experiment (experiment No. 1) and vessels of the vegetation experiment (experiment No. 2). They were dried, ground, sifted through a sieve with $1 \mathrm{~mm}$ holes and placed in polyethylene columns with a diameter of $65 \mathrm{~mm}$. The mass of soil in the column was $800 \mathrm{~g}$. The height of the soil layer was $18 \mathrm{~cm}$. The packing density was $1.0-1.1 \mathrm{~g} / \mathrm{cm}^{3}$. Repeat was 6 -fold. The soil in the columns was saturated with deionized water to the first drop of leaked moisture. Then, washing was performed using $400 \mathrm{ml}$ of water. After washing, the filtrate was collected in a flask.

$0.1 \mathrm{~N} \mathrm{NaOH}$ was added to the eluates, adjusting the $\mathrm{pH}$ to 13 units. Upon reaching the specified $\mathrm{pH}$ value, brown OMC flakes precipitated, which were separated from the supernatant, dried and analyzed, setting the content of Corg, $\mathrm{E}_{\mathrm{s}}^{\mathrm{mg} / \mathrm{ml}}$ and the presence of $\mathrm{Al}$, $\mathrm{Mn}$ and $\mathrm{Fe}$.

Soil samples for experiment No. 1 were taken from the plots of the microfield experiment one year after liming after harvesting peas (Pisum sativum). The experience was laid in 2015 to study the reclamation properties of the screening of dolomite used for road construction. The particle size of dolomite was 5-7 and 7-10 $\mathrm{mm}$. The research methodology is described in detail in the works [11-12]. Repeat was 4-fold. The experimental scheme is shown in Table. 1 . The dose of the reclamation agent is calculated by hydrolytic acidity of $7.35 \mathrm{t} / \mathrm{ha}$. For comparison, dolomite flour (DF) was used, prepared from the screenings passed through a sieve with $0.25 \mathrm{~mm}$ holes. An option with a natural mixture of screening particles (NMP) is included in the experimental scheme. The particle size distribution of screenings is given in [11].

The content of $\mathrm{CaCO}_{3}$ in dolomite is $46.1 \%$; $\mathrm{MgCO}_{3}$ is $38.4 \%$.

In the experiment used Umbric Albeluvisol Abruptic: $\mathrm{pH}_{\mathrm{KCl}}-4.6 ; \mathrm{Ng}-4.9$ $\mathrm{mmol}(\mathrm{eq}) / 100 \mathrm{~g}$ of soil, humus -2.18 . Particle content less than $0.01 \mathrm{~mm}-21.4 \%$.

In experiment No. 2, the composition of OMCs migrating from Umbric Albeluvisol Abruptic, reclaimed by CC (waste from the production of mineral fertilizers), was established in an amount of $2.5 \mathrm{Ng} 20.25$ t/ha. The chalk content of $\mathrm{CaCO}_{3}$ is $90 \%$. Soil samples were taken from the vessels of the growing experiment 5 years after reclamation. Umbric Albeluvisol Abruptic was used for the growing experiment: $\mathrm{pH}_{\mathrm{KCl}}-4.1 ; \mathrm{Ng}-5.4$ 
mmol(eq)/100 g of soil; humus $-3.02 \%$. Particle content $<0.01 \mathrm{~mm}$ was $18.6 \%$. The experimental conditions are described in detail in [13].

The determination of carbon in the composition of the sediments was carried out according to the method of I.V. Tyurin, based on the oxidation of humus with a sulfurchromium mixture in a ratio of $1: 1$. The optical density of OMC was measured at FEC, predissolving the precipitate in $0.1 \mathrm{~N} \mathrm{NaOH}$. The method of T.A. Plotnikova, V.V. Ponomareva [14] was used. The wavelength was $430 \mathrm{~nm}$, the thickness of the cell was 1 $\mathrm{cm}$.

The content of $\mathrm{Al}, \mathrm{Mn}$, and Fe in the sediments was determined on an ICPE-9000 emission spectrophotometer (Shimadzu, Japan) according to the manufacturer's method. For this, the samples were ground and ashed in a mixture of concentrated $\mathrm{HNO}_{3}$ and $38 \%$ $\mathrm{H}_{2} \mathrm{O}_{2}$ (1:1) at $70{ }^{\circ} \mathrm{C}$ using the DigiBlock system (LabTech, Italy).

\section{Results and discussion}

The maximum reclamation effect of liming (table 1) was achieved in the experimental variants using DF, a natural mixture of dolomite fractions (NMP) and particles of 7-10 mm in size $\left(\mathrm{pH}_{\mathrm{KCl}}\right.$ was established at the level of 5.6-5.7 units). The effect of using particles with a size of 5-7 mm was lower $\left(\mathrm{pH}_{\mathrm{KCl}}\right.$ 5.3). In experiment No. 2, 5 years after liming and placement in columns, $\mathrm{pH}_{\mathrm{KCl}}$ of the soil is close to neutral $\left(\mathrm{pH}_{\mathrm{KCl}} 6.3\right)$.

Table 1. Composition of organo-mineral complexes washed out from reclaimed Umbric Albeluvisol Abruptic.

\begin{tabular}{|c|c|c|c|c|c|c|c|}
\hline \multirow{2}{*}{$\begin{array}{l}\text { Experiment } \\
\text { option }\end{array}$} & \multirow{2}{*}{$\mathrm{pH}_{\mathrm{KCl}}$} & \multirow{2}{*}{ Ctotal, \% } & \multirow{2}{*}{$\mathrm{E}_{\mathrm{s}}^{\mathrm{mg} / \mathrm{ml}}$} & \multicolumn{4}{|c|}{ Metal content, $\mathrm{mg} / \mathrm{kg}$} \\
\hline & & & & $\mathrm{Al}$ & $\mathrm{Fe}$ & $\mathrm{Mn}$ & Total \\
\hline \multicolumn{8}{|c|}{ Experience No. 1 (ameliorant - dolomite crumb) } \\
\hline $\begin{array}{c}\text { 1. NPK } \\
\text { (background) }+ \\
\text { Dolomite (D) }< \\
0.25 \mathrm{~mm}(1 \mathrm{Ng})\end{array}$ & $5.7 \pm 0.1 \mathrm{~b}$ & $5.60 \pm 0.04 \mathrm{~b}$ & $3.1 \pm 0.3 \mathrm{a}$ & $1333 \pm 39 b$ & $167 \pm 3 \mathrm{a}$ & $2640 \pm 4 b$ & $4139 \pm 43 b$ \\
\hline $\begin{array}{l}\text { 2. Background } \\
+\mathrm{D} 5-7 \mathrm{~mm}(1 \\
\mathrm{Ng})\end{array}$ & $5.3 \pm 0.1 \mathrm{a}$ & $5.69 \pm 0.01 \mathrm{c}$ & $2.7 \pm 0.1 \mathrm{a}$ & $3968 \pm 14$ e & $496 \pm 3 d$ & $18716 \pm 95 \mathrm{e}$ & $2318 \pm 91 \mathrm{a}$ \\
\hline $\begin{array}{l}\text { 3. Background } \\
+\mathrm{D} 7-10 \mathrm{~mm}(1 \\
\mathrm{Ng})\end{array}$ & $5.6 \pm 0.1 \mathrm{~b}$ & $5.59 \pm 0.01 b$ & $2.9 \pm 0.1 \mathrm{a}$ & $3253 \pm 13 d$ & $424 \pm 4 c$ & $13635 \pm 23 \mathrm{~d}$ & $17372 \pm 28 \mathrm{~d}$ \\
\hline $\begin{array}{l}\text { 4. Background } \\
+ \text { NMP }(1 \mathrm{Ng})\end{array}$ & $5.7 \pm 0.1 \mathrm{~b}$ & $5.51 \pm 0.01 \mathrm{a}$ & $2.8 \pm 0.1 \mathrm{a}$ & $1861 \pm 4 \mathrm{c}$ & $359 \pm 6 b$ & $4356 \pm 10 \mathrm{c}$ & $6576 \pm 6 \mathrm{c}$ \\
\hline \multicolumn{8}{|c|}{ Experience No. 2 (ameliorant - conversion chalk) } \\
\hline $\begin{array}{l}1 . \mathrm{NPK} \\
\text { (background })+ \\
\mathrm{CC}(2.5 \mathrm{Ng})\end{array}$ & $6.3 \pm 0.1 \mathrm{c}$ & $5.50 \pm 0.02 \mathrm{a}$ & $3.0 \pm 0.3 \mathrm{a}$ & $1693 \pm 11 \mathrm{a}$ & $605 \pm \mathrm{e}$ & $903 \pm 7 \mathrm{a}$ & $3202 \pm 29$ \\
\hline \multicolumn{8}{|c|}{$\begin{array}{l}\text { Mean values and }( \pm) \text { standard errors of the mean }(\mathrm{n}=3) \text { are indicated. Different Latin letters indicate } \\
\text { significant differences between the options according to the criterion of the smallest average difference }(\mathrm{SAD}) \\
\text { of Fisher }(\mathrm{P}<0.01) \text {. }\end{array}$} \\
\hline
\end{tabular}

The amount of Corg in OMC ranged from 5.5 to $5.7 \%$.

The optical density Esmg/ml of OMC in experiment No. 1 ranged from 2.7 to 3.1 units. In experiment No. $2-E s m g / m l=3$. This corresponds to the optical density of the FC, which fits into the range from 1 to 4 units [15].

The scale of $\mathrm{Al}$ migration in experiment No. 1 depended on the size of the particles. By the amount of aluminum removed during OMC migration, all the studied variants can be arranged in the following descending sequence: particles with sizes 5-7 mm> 7-10 mm> NMP $>$ particles less than $0.25 \mathrm{~mm}$. The use of finely divided dolomite $(<0.25 \mathrm{~mm})$ reduced the migration mobility of aluminum by 2.98 and 2.44 times, respectively. The 
amount of migrating aluminum in the OMC composition of experiment No. 2 with CC was higher than in the variant with DF and lower than in the variant with NMP in experiment No. 1 .

In experiment No. 1, the content of manganese migrating as part of OMC ranged from 2639.5 to $18715.6 \mathrm{mg} / \mathrm{kg}$. This was $1.98-4.71$ times the amount of aluminum. The amount of migrating manganese in experiment No. 2 was 1.88 times less than that of aluminum.

The influence of the degree of grinding of dolomite on the amount of manganese bound in the composition of OMC is much stronger than that of aluminum.

Depending on the experiment option, the content of migrating iron was 7.7-8.0 times less than aluminum and 15.8-32.1 times lower than manganese. In experiment No. 1, the amount of washed iron ranged from $166.8 \mathrm{mg} / \mathrm{kg}$ (option with DF) to $495.9 \mathrm{mg} / \mathrm{kg}$ (option with particles 5-7 $\mathrm{mm}$ in size). The difference was 2.97 times.

In experiment No. 1, the migrating elements formed the following descending sequence: $\mathrm{Mn}>\mathrm{Al}>\mathrm{Fe}$. In experiment No. 2, the content of washed Al in OMC exceeded the contents of Fe and Mn by 2.8 and 1.87 times, respectively.

Fulvic acids migrating as part of $\mathrm{OMC}$ bind a large amount of $\mathrm{Ca}, \mathrm{Mg}$, and $\mathrm{Sr}$ (Pavlova et al., 2018). The smaller the grinding fineness of dolomite, the more alkaline earth metals migrated as part of OMC. In experiment No. 1, fluctuations in their total content ranged from 191 to $319 \mathrm{~g} / \mathrm{kg}$ of precipitate. Base-averaged FAs retain "aggressiveness" with respect to soil minerals, transferring $\mathrm{Al}, \mathrm{Mn}$, and $\mathrm{Fe}$ into a solution. The larger the particle size of the ameliorant and the smaller the bases $\mathrm{Ca}, \mathrm{Mg}$ and $\mathrm{Sr}$ contain $\mathrm{OMC}$, the higher the "aggressiveness" of FA. The relationship between the total amount of $\mathrm{Ca}, \mathrm{Mg}$, and $\mathrm{Sr}$ washed out and the sum of Al, Mn, and Fe migrating in experiment No. 1 is weak negative: $r=-0.2$. Using even $20.25 \mathrm{t} /$ ha of CC does not eliminate the destruction of minerals.

Consequently, the processes of acid hydrolysis of minerals in reclaimed soils do not stop. Liming does not eliminate the influence of climatic factors on the processes of humus formation. The resulting humic acids remain acidic and even after neutralization with lime ameliorants, some functional groups have a destructive effect on soil minerals.

\section{Conclusions}

1. The content of carbon migrating as part of OMC in sod-podzolic reclaimed soils ranged from 5.5 to $5.7 \%$. The OMC optical density values were within the range typical for fulvic acids $\left(\mathrm{E}_{\mathrm{s}}^{\mathrm{mg} / \mathrm{ml}}=2.7-3.1\right)$.

2. The processes of acid hydrolysis of minerals in lime soils do not stop. The total amount of $\mathrm{Al}, \mathrm{Mn}$, and $\mathrm{Fe}$ washed out in the OMC composition depended on the size of the ameliorant particles, the weathering of the surface of its particles, and the content of alkaline-earth metals in the OMC. Fluctuations in the total content of typomorphic elements in $\mathrm{OMC}$ in various experiment options with dolomite particles ranged from 2317.8 to $13371 \mathrm{mg} / \mathrm{kg}$. In the experiment with CC, they were $3201.6 \mathrm{mg} / \mathrm{kg}$.

3. Regardless of experiment option with dolomite particles, the migrating typomorphic elements formed the following descending sequence: $\mathrm{Mn}>\mathrm{Al}>\mathrm{Fe}$. The content of eluted manganese was 7.7-8.0 times higher than the amount of aluminum washed out and 15.832.1 times the amount of migrating iron. In the experiment with $\mathrm{CC}$, the content of washed aluminum in the OMC composition exceeded the content of Fe and Mn by 2.8-1.87 times, respectively.

Analysis of the content of elements in the sediments was supported by the Russian Science Foundation (grant 19-16-00097). 


\section{References}

1. Stuckey J W, Goodwin C, Wang J, Kaplan L A, Vidal-Esquivel P, Beebe T P, Jr and Sparks D L 2018 Impacts of hydrous manganese oxide on the retention and lability of dissolved organic matter Geochemical Transactions 19(1) doi:10.1186/s12932-0180051-x

2. Newcomb C J, Qafoku N P, Grate J W, Bailey V L and De Yoreo J 2017 Developing a molecular picture of soil organic matter-mineral interactions by quantifying organomineral binding Nature Communications 8(1) doi:10.1038/s41467-017-00407-9

3. Han L, Sun K, Jin J and Xing B 2016 Some concepts of soil organic carbon characteristics and mineral interaction from a review of literature Soil Biology and Biochemistry 94 107-121 doi:10.1016/j.soilbio.2015.11.023

4. Nierop, K G J, Jansen, B and Verstraten, J M 2002 Dissolved organic matter, aluminium and iron interactions: Precipitation induced by metal/carbon ratio, $\mathrm{pH}$ and competition Science of the Total Environment 300(1-3) 201-211 doi:10 1016/S00489697(02)00254-1

5. Kalbitz K, Kaiser K. 2008 Contribution of dissolved organic matter to carbon stogare in forest mineral soils J. Plant Nutr. Soil Science 171(1) 52-60

6. Kaurichev I S, Nozdrunova E P 1969 The conditions of formation and the extent of migration of organo-mineral compounds in the soils of the taiga-forest zone Bulletin of Russian State Agrarian University (Moscow Timiryazev Agricultural Academy) 3 103-110

7. Yerima B P K, Enang R K, Kome G K, Van Ranst E 2020 Exchangeable aluminium and acidity in Acrisols and Ferralsols of the north-west highlands of Cameroon Geoderma Regional 23 https://doi.org/10.1016/j.geodrs.2020.e00343

8. Ponomareva V V 1949 About the reactions of the group of crenic and apocrenic acids (fulvic acids) with hydroxides of the base Soil Science № 11 638-651

9. Pavlova O Yu, Litvinovich A V, Lavrishchev A V, Shevchenko E E, Salaev I V and Belimov A A 2018 The study of soil solutions leached from reclaimed sod-podzolic soils Agrochemistry № 12 69-76

10. Nebolsin A N, Nebolsina Z P 2010 Liming of soils (Saint Petersburg) p 254

11. Litvinovich A V, Pavlova O Yu, Lavrishchev A V, Bure V M and Kovleva A O 2016 Reclamation properties, fertilizer value and dissolution rate in soils of different sizes of dolomite screenings used for road construction Agrochemistry № 2 31-41

12. Litvinovich A V, Salaev I V, Pavlova O Yu, Lavrishchev A V, Bure V M and Saljnikov E 2019 Utilization of large-sized dolomite by-product particles and losses of cations from acidic soil Communications in Soil Science and Plant Analysis 50(7) 1-9

13. Litvinovich A, Pavlova O, Lavrishchev A, Bure V and Saljnikov E 2017 Empirical models of transformations of humic acids and humin in umbric albeluvisol abruptic as influenced by_liming Zemdirbyste 104(2) 115-122 doi: 10 13080/z-a 2017104015

14. Plotnikova T A, Ponomareva V V 1967 A simplified version of the method for determining the optical density of humic substances with one light filter Soil Science № 7 73-85

15. Bakina L G 2012 The role of fractions of humic substances in soil-ecological processes PhD thesis (Saint Petersburg) p 381 